Corresponding Author:

Fendie K. Syailawan;

email: fendieks@gmail.com

Received: 26 March 2019

Accepted: 12 April 2019

Published: 30 April 2019

Production and Hosting by

Knowledge E

(c) Fendie K. Syailawan et al. This article is distributed under the terms of the

Creative Commons

Attribution License, which

permits unrestricted use and redistribution provided that the original author and source are credited.

Editor-in-Chief:

Dr. Dimitrios Papandreou

Official Publication of Zayed University, UAE

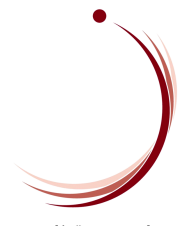

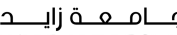
ZAYED UNIVERSITY

G OPEN ACCESS
Research Article

\section{Effect of Soy Milk and Mung Bean Porridge on Serum Triglycerides among Postmenopausal Women}

\author{
Fendie K. Syailawan ${ }^{1}$, Budiyanti Wiboworini ${ }^{1}$, and Lilik Retna Kartikasari ${ }^{2}$ \\ ${ }^{1}$ Master's Degree Program in Nutrition Science, Graduate School, Universitas Sebelas Maret, \\ Surakarta, Indonesia \\ ${ }^{2}$ Faculty of Agriculture, Universitas Sebelas Maret, Surakarta, Indonesia
}

\section{Abstract}

Aim: This study aimed to analyze the effect of soy milk and mung bean porridge on serum triglycerides among postmenopausal women. Methods: This was an experimental study using pretest and posttest with control group. Subjects of this study were 30 postmenopausal women aged 45-75 in Serengan District, Surakarta. Subjects were divided into control group $(n=10)$, soy milk group $(n=10$ ) and combination of soy milk and mung bean porridge group $(n=$ 10). The soy milk and mung bean porridge provided were $240 \mathrm{ml}$ and $180 \mathrm{ml}$ per day per person, respectively. The study was carried out for 4 weeks from December 2018 to January 2019. The collected data were analyzed with paired t-test and Wilcoxon test. Results: There was a slight decrease in serum triglycerides level in all groups, but it was not statistically significant ( $p>0,05)$. Conclusions: Although soy milk and mung bean porridge contain many antihypertriglyceridemic nutrients, there is no significant effect on serum triglycerides among postmenopausal women. Further study with longer duration and more sample size is needed.

Keywords: Soy milk, mung bean porridge, triglycerides, postmenopausal women

\section{Introduction}

Hypertriglyceridemia is one of the risk factors for cardiovascular disease $[1,19]$. Before menopause, women suffer from heart disease less often than men because of the protective effect of female sex hormone, estrogen [20]. Serum triglyceride level statistically shows significant increase among postmenopausal women compared to premenopausal women [15]. Moreover, triglycerides and waist circumference often correlates positively [25]. In various studies in several Asian countries, prevalence of women with hypertriglyceridemia was almost close to the prevalence in men [14]. According to Riskesdas (National Baseline Health Research) in 2013, the prevalence of hypertriglyceridemia in Indonesia among women was $11.7 \%$ which was not significantly different from prevalence among men, i.e. 15.1\% [17]. Among adults, hypertriglyceridemia is usually caused by weight gain, lack of exercise, diet high in simple carbohydrates, sweet drinks and smoking [7, 12]. 
Dietary changes are key element in the first-line management of hypertriglyceridemia [2]. Soybean has many health benefits, one of which is as antihypertriglyceridemia. Soybeans contain low calories, $0 \%$ cholesterol, $0 \%$ trans fatty acids, high protein, high isoflavones, high fiber and low fat $[23,24]$. There are also other compounds in soybeans namely phytosterols and saponins which can help reduce serum triglycerides $[3,8,16]$. Phytosterol compounds can inhibit the absorption of fat in the small intestine and reduce lipogenesis in the liver in experimental animals so it can reduce serum triglyceride levels [21]. While saponins are known to reduce triglycerides by regulating mechanism of fat absorption [16].

Mung bean contains protein and fiber, low fat, low calorie, and enough resistant starch. It also contains flavonoids, especially vitexin of $157.5 \mathrm{mg} / 100 \mathrm{~g}$ and isovitexin of $198.5 \mathrm{mg} / 100 \mathrm{~g}$ [5]. Resistant starch regulates metabolic pathways, maintains serum sugar levels after meals thereby reducing serum triglyceride levels [5, 6]. Vitexin and isovitexin play a role in reducing lipogenesis due to inflammation, oxidative stress and lipid synthesis so that it can reduce serum triglyceride levels [8, 13].

Soybean in the form of milk and mung bean in the form of porridge are the most commonly consumed beverage and snack among Indonesian people. Research regarding effects of soy milk and mung bean porridge on serum triglycerides has not been done much, especially related to its effect on postmenopausal women. The purpose of this study was to analyze the effect of soy milk and mung bean porridge on serum triglycerides among postmenopausal women.

\section{Methods}

This was an experimental study using pretest and posttest with control group design. The inclusion criteria were women aged 45-75 who have stopped menstruating for at least 1 year and had serum triglyceride levels between 150 and $450 \mathrm{mg} / \mathrm{dl}$. In this study, the exclusion criteria were taking drugs or supplements that affect serum triglycerides, undergoing a weight loss diet, consuming alcohol, allergic against soybean or mung bean, immobilized and smoking. In addition, subjects that had cardiovascular and kidney disease were also excluded. Treatment was conducted for 4 weeks from December 2018 to January 2019. The subjects of this study were postmenopausal women in Joyotakan Village and Danukusuman Village, Serengen District, Surakarta. The subjects were selected using consecutive sampling. Total subjects were 30 women which were obtained based on the Murti formula regarding comparison of the mean of two populations and Keshavarz's study $[10,18]$. A simple randomization was then performed to determine the control group $(n=10)$, the group that received soy milk $(n=10)$ and the group that received both soy milk and mung bean porridge $(n=10)$. All subjects received oral and written nutritional counseling about low-fat and lowcholesterol diet for 4 times according to the guidelines from Ministry of Health of Indonesia. In order to assess the subject's food intake during the intervention, 24-hour dietary recall was carried out 3 times.

The dosage of soy milk used in this study was $240 \mathrm{ml} / \mathrm{per}$ subject/per day obtained from Keshavarz's study [10]. Referring to the study of Fitrianti \& Marthandaru, soy milk 
was modified by adding low calorie sugar of $0.5 \mathrm{~g}(1 \mathrm{kcal}) / 240 \mathrm{ml}$ soy milk [4]. The dosage of mung bean porridge provided was $180 \mathrm{ml} / \mathrm{subject} / \mathrm{day}$ based on the Tachibana study regarding effective dosage of mung bean protein that can reduce triglycerides [22]. Mung bean porridge was made based on the most common method used by the people in Surakarta, but was modified by adding brown sugar of $5.6 \mathrm{~g}(22 \mathrm{kcal})$. The nutritional value of soy milk and mung bean porridge used in this study can be seen on Table 1. Before the intervention, hedonic test about the preference and acceptance of prospective subjects for soy milk and mung bean porridge had been carried out among similar population. Soy milk was consumed 3 hours after lunch, while mung bean porridge was given 1 hour after soy milk.

The research data used in the study were primary data including serum triglyceride levels. Data were obtained from pretest (before intervention) and posttest (after intervention). Data of serum triglycerides were measured using GPO-PAP (enzymatic colorimetric assay) method by fasting 12 hours before blood collection. The collected data were then processed using paired t-test and Wilcoxon test.

\subsection{Ethical consideration}

This study was approved by Health Research Ethics Committee (HREC) of Universitas Sebelas Maret with certificate number 349/UN27.6/KEPK/2018. All procedures followed were in accordance with the ethical standards of HREC. Moreover, prior to screening and intervention, all subjects had already signed an informed consent.

\section{Results}

The subjects who participated in this study were 30 women and no one dropped out. The characteristics of the subjects consisted of nutritional status, education level, occupation, average of age, average of BMI (body mass index) and global physical activity questionnaire (GPAQ) score. The highest average age was found in the soy milk group while subjects with the highest BMI was found in the control group. Moreover, the soy milk and the combination group had more low-educated subjects and more preobese subjects than the control group. The physical activities of the subjects calculated using GPAQ showed that the lowest physical activity score occurred in the combination group and was then followed by the soy milk group (Table 2). From dietary recall, the soy milk group had the highest energy, fat, protein, fiber and carbohydrate intake (Table 3).

The decrease in triglycerides occurred in almost all groups, while the highest decrease occurred in the control group. However, those decreases were not statistically significant $(p>0.05)$ (Table 4). 
TABLE 1: Nutritional Value of Provided Soy Milk and Mung Bean Porridge.

Nutrients
Water (\%)
Ash (\%)
Fat (\%)
Protein (\%)
Crude Fiber (\%)
Carbohydrates (\%)
Calorie (cal/g)

\begin{tabular}{|c|}
\hline Soy Milk \\
\hline 95.34 \\
\hline 0.23 \\
\hline 1.13 \\
\hline 1.57 \\
\hline 0.21 \\
\hline 1.78 \\
\hline 25.64 \\
\hline
\end{tabular}

\begin{tabular}{|c|}
\hline $\begin{array}{c}\text { Mung Bean } \\
\text { Porridge }\end{array}$ \\
\hline 89.64 \\
0.47 \\
0.17 \\
\hline 2.56 \\
\hline 0.30 \\
7.17 \\
\hline 72.37
\end{tabular}

Source: Primary Data, 2019

TABLE 2: Characteristics of Research Subjects $(n=30)$.

\begin{tabular}{|c|c|c|c|}
\hline Characteristics & $\begin{array}{l}\text { Control Group } \\
(n=10) \%\end{array}$ & $\begin{array}{l}\text { Soy Milk Group } \\
(n=10) \%\end{array}$ & $\begin{array}{l}\text { Combination } \\
\text { Group }(n=10) \%\end{array}$ \\
\hline \multicolumn{4}{|l|}{ Nutritional Status } \\
\hline Normal & $2(20 \%)$ & $3(30 \%)$ & $2(20 \%)$ \\
\hline Overweight & $2(20 \%)$ & $3(30 \%)$ & 3 (30\%) \\
\hline Preobese & $3(30 \%)$ & $5(50 \%)$ & $5(50 \%)$ \\
\hline Obese & $3(30 \%)$ & 0 (0\%) & $1(10 \%)$ \\
\hline \multicolumn{4}{|l|}{ Education Level } \\
\hline Elementary School & $1(10 \%)$ & $2(20 \%)$ & $6(60 \%)$ \\
\hline Junior High School & $3(30 \%)$ & 5 (50 \%) & $2(20 \%)$ \\
\hline Senior High School & $3(30 \%)$ & $2(20 \%)$ & $2(20 \%)$ \\
\hline Bachelor & $3(30 \%)$ & $1(10 \%)$ & $0(0 \%)$ \\
\hline \multicolumn{4}{|l|}{ Occupation } \\
\hline Housewife & $8(80 \%)$ & 7 (70\%) & $6(60 \%)$ \\
\hline Entrepreneur & 1 (10\%) & $1(10 \%)$ & $4(40 \%)$ \\
\hline Employee & $1(10 \%)$ & $2(20 \%)$ & 0 (0\%) \\
\hline Mean of Age & 56.1 & 59.5 & 58.4 \\
\hline Mean of BMI & 27.5 & 25.9 & 25.7 \\
\hline Average of GPAQ Score & 694 & 562 & 536 \\
\hline
\end{tabular}

GPAQ: global physical activity questionnaire,

Source: Primary Data, 2019

TABLE 3: Average of Food Intake from 24-hour Dietary Recall.

\begin{tabular}{|l|c|c|c|c|c|}
\hline Group & Energy (kcal) & Protein (g) & Fat (g) & $\begin{array}{c}\text { Carbohydrates } \\
\text { (g) }\end{array}$ & Fiber (g) \\
\hline Control & 1397.6 & 45.0 & 45.8 & 209.9 & 12.8 \\
\hline Soy Milk & 1696.1 & 67.1 & 58.7 & 230.9 & 20.2 \\
\hline Combination & 1366.7 & 53.8 & 48.6 & 183.7 & 17.0 \\
\hline
\end{tabular}

Source: Primary Data, 2019 
TABLE 4: Paired t-test \& Wilcoxon Test of Serum Triglycerides (TG).

\begin{tabular}{|l|c|c|c|c|c|}
\hline Group & $\mathbf{n}$ & $\begin{array}{c}\text { TG }(\text { Mean } \pm \text { SD) } \\
\text { pretest }(\mathbf{m g} / \mathbf{d l})\end{array}$ & $\begin{array}{c}\text { TG }(\text { Mean } \pm \text { SD) } \\
\text { posttest }(\mathbf{m g} / \mathbf{d l})\end{array}$ & $\begin{array}{c}\Delta \text { Mean } \\
\text { (mg/dl) }\end{array}$ & p value \\
\hline Control & 10 & $191.10 \pm 34.61$ & $178.60 \pm 85.49$ & -12.50 & $0.114(w)$ \\
\hline Soy Milk & 10 & $273.40 \pm 81.00$ & $263.40 \pm 95.84$ & -10.00 & $0.679 *$ \\
\hline Combination & 10 & $232.70 \pm 81.71$ & $229.40 \pm 89.37$ & -3.30 & $0.646(w)$ \\
\hline
\end{tabular}

*paired t-test, $\mathrm{w}=$ wilcoxon test

Source: Primary Data, 2019

\section{Discussion}

Tokede et al. (2015) and Ganesan et al. (2018) suggest that soy bean and mung bean can help reduce serum triglycerides, but this effect cannot be proven on postmenopausal women $[5,23]$. The decreased serum triglyceride levels in all groups may be caused by dietary recommendations carried out by all subjects. Besides food, triglycerides are also affected by other factors such as weight gain, exercise, smoking and physical activity $[7,12]$. Physical activity of subjects in the control group was indeed higher than other groups, so it could be one of the causes of more decrease in triglycerides in the control group. Moreover, the insignificant decrease in triglycerides could have occurred due to lack of fiber consumption in all three groups, which was still below daily recommendation (25 g/day). In addition, fat intake in control group seems to be the lowest among the others, so it could be also a factor affecting this decrease.

It seems that the subjects in soy milk and combination groups have the lowest education level, so it could affect the compliance. Aside from that, soy milk and combination groups have more preobese subjects than the control group, so it could also impair the decrease of triglycerides level because the higher waist circumference is, the more triglycerides will raise [25]. This study has some limitations, such as small sample size, the scope of the study is only in Surakarta and the duration of the study was only 4 weeks.

\section{Conclusion}

Although both soy milk and mung bean porridge contain many antihypertriglyceridemic nutrients, there is no significant effect on serum triglycerides among postmenopausal women. Besides dietary intervention, physical activity and routine exercise are also needed to help reduce serum triglycerides. Moreover, caution is needed in adding sugar to soy milk and mung bean porridge. Further study with longer duration and more sample size is needed to analyze the effect of soy milk and mung bean porridge on serum triglycerides. 


\section{Acknowledgement}

We would also like to show our gratitude to Dr. Diffah Hanim, Dra., M.Si as Head of Master's Degree Program in Nutrition Science, Universitas Sebelas Maret for sharing her pearls of wisdom with us during the course of this research. We are also immensely grateful to all of lecturers in Department of Nutrition Science, Graduate School, Universitas Sebelas Maret for their support during the research and comments on this manuscript.

\section{References}

[1] Arca, M., Borghi, C., Pontremoli, R., et al. (2017). Hypertriglyceridemia and Omega-3 Fatty Acids: Their Often Overlooked Role in Cardiovascular Disease Prevention. Nutrition, Metabolism and Cardiovascular Diseases, vol. 28, no. 3, pp. 197-205. DOI: 10.1016/j.numecd.2017.11.001

[2] Berglund, L., Brunzell, J. D., Goldberg, A. C., et al. (2012). Evaluation and Treatment of Hypertriglyceridemia: An Endocrine Society Clinical Practice Guideline. The Journal of Clinical Endocrinology and Metabolism, vol. 97, no. 9, pp. 2969-2989. DOI: 10.1210/jc.2011-3213

[3] Clifton, P. M., Mano, M., Duchateau, G. S. M. J., et al. (2008). Dose-response Effects of Different Plant Sterol Sources in Fat Spreads on Serum Lipids and C-reactive Protein and on the Kinetic Behavior of Serum Plant Sterols. European Journal of Clinical Nutrition, vol. 62, no. 8, pp. 968-997. DOI: 10.1038/sj.ejcn.1602814

[4] Fitrianti, D. Y., and Marthandaru, D. (2016). Effect of Soy Milk and Ginger on Total Cholesterol among Women. Jurnal Gizi Indonesia, vol. 4, no. 2, pp. 89-95. DOI: 10.14710/jgi.4.2.89-95

[5] Ganesan, K., and Xu, B. A. (2018). Critical Review on Phytochemical Profile and Health Promoting Effects of Mung Bean (Vigna radiata). Food Science and Human Wellness, vol. 7, no. 1, pp. 11-33. DOI: 10.1016/j.fshw.2017.11.002

[6] Higgins, J. (2014). Resistant Starch and Energy Balance: Impact on Weight Loss and Maintenance. Critical Reviews in Food Science and Nutrition, vol. 54, no. 9, pp. 1158-1166. DOI: 10.1080/10408398.2011.629352

[7] Johnson, R. K., Appel, L. J., Brands, M., et al. (2009). Dietary Sugars Intake and Cardiovascular Health: a scientific statement from the American Heart Association. Circulation, vol. 120, no. 11, pp. 1011-1020. DOI: 10.1161/CIRCULATIONAHA.109.192627

[8] Kang, I. H., Chi, S. J., Ha, T. J., et al. (2015). Effects of Mung Bean (Vigna radiata L.) Ethanol Extracts Decrease Proinflammator Cytokine-Induced Lipogenesis in the KK-Ay Diabese Mouse Model. Journal of Medicinal Food, vol. 18, no. 8, pp. 841-849. DOI: 10.1089/jmf.2014.3364

[9] Kang, J., Badger, T. M., Ronis, M. J. J., et al. (2010). Non-isoflavone Phytochemicals in Soy and Their Health Effects. Journal of Agricultural and Food Chemistry, vol. 58, no. 14, pp. 8119-8133. DOI: 10.1021/jf100901b

[10] Keshavarz, S. A., Nourieh, Z., Attar, M. J. H., et al. (2012). Effect of Soy Milk Consumption on Waist Circumference and Cardiovascular Risks among Overweight and Obese Female Adults. International Journal of Preventive Medicine, vol. 3, no. 11, pp. 798-805.

[11] Kim, D. K., Jeong, S. C., Gorinstein, S., et al. (2012). Total Polyphenols:Antioxidant and Antiproliferative Activities of Different Extracts in Mungbean Seeds and Sprouts. Plant Foods for Human Nutrition, vol. 67, no. 1, pp. 71-75. DOI: 10.1007/s11130-011-0273-x

[12] Koda, M., Kitamura, I., Okura, T., et al. (2016). The Associations Between Smoking Habits and Serum Triglyceride or Hemoglobin A1c Levels Differ According to Visceral Fat Accumulation. Journal of Epidemiology, vol. 6, no. 4, pp. 208-215. DOI: 10.2188/jea.JE20150086

[13] Li, H., Cao, D., Yi, J., et al. (2012). Identification of the Flavonoids in Mungbean (Phaseolus radiatus L) Soup and Their Antioxidant Activities. Food Chemistry, vol. 135, no. 4, pp. 2942-2946. DOI: 10.1016/j.foodchem.2012.07.048

[14] Lin, C., Chang, Y., Chien, S., et al. (2018). Epidemiology of Dyslipidemia in the Asia Pacific Region. International Journal of Gerontology, vol. 12, no. 2, pp. 2-6. DOI: https://doi.org/10.1016/j.ijge.2018.02. 010

[15] Manafa, P. O., Aguiyi, N. C., Onyenekwe, C. C., et al. (2015). Comparative Assessment of Lipid Profile in Pre-menopausal dan Menopausal Women in Nnewi Nigeria. European Scientific Journal, vol. 11, no. 3 , pp. 1857-1881. 
[16] Marelli, M., Conforti, F., Araniti, F., et al. (2016). Effects of Saponins on Lipid Metabolism: A Review of Potential Health Benefits in the Treatment of Obesity. Molecules, vol. 21, no. 10, pp. E1404. DOI: 10.3390/molecules21101404

[17] Ministry of Health of Indonesia. (2013). National Baseline Health Research. Badan Penelitian dan Pengembangan Kesehatan, Jakarta.

[18] Murti B. (2016). Principal and Methods of Epidemiological Study. $4^{\text {th }}$ Edition. Master's Program in Public Health. Surakarta: Graduate School, Universitas Sebelas Maret.

[19] Nordestgaard, B. G., and Varbo, A. (2014). Triglycerides and Cardiovascular Disease. Lancet, vol. 384 no. 9943, pp. 626-635. DOI: https://doi.org/10.1016/S0140-6736(14)61177-6

[20] Palmisano, B. T., Zhu, L., and Stafford, J. M. (2017). Estrogens in the Regulation of Liver Lipid Metabolism. Advances in Experimental Medicine and Biology, vol. 1043, no. 1, pp. 227-256. DOI: 10.1007/978-3-31970178-3_12

[21] Rideout, T. C., Ramprasath, V., Griffin, J. D., et al. (2014). Phytosterols protect against diet-induced hypertriglyceridemia in Syrian golden hamsters. Lipids in Health and Disease, vol. 6, no. 13, pp. 5. DOI: 10.1186/1476-511X-13-5

[22] Tachibana, N., Wanezaki, S., Nagata, M., et al. (2013). Intake of Mung Bean Protein Isolate Reduces Plasma Triglyceride Levelin Rats. Functional Foods in Health and Disease, vol. 3, no. 9, pp. 365-376. DOI: $10.31989 /$ ffhd.v3i9.39

[23] Tokede, O. A., Onabanjo, T. A., Yansane, A., et al. (2015). Soya Products and Serum Lipids: a MetaAnalysis of Randomised Controlled Trials. The British Journal of Nutrition, vol. 114, no. 6, pp. 831-843. DOI: $10.1017 /$ S0007114515002603

[24] USDA (United States Department of Agriculture). (2018). Food Composition Databases Show Foods List (accessed from https://ndb.nal.usda.gov/ndb/search/list on 12 July, 2018).

[25] Zhang, A., Yao, Y., Xue, Z., et al. (2018). A Study on the Factors Infuencing Triglyceride Levels among Adults in Northeast China. Scientific Reports, vol. 8, no. 1, pp. 6388. DOI: 10.1038/s41598-018-24230-4 